\title{
AS QUATRO FUNDAÇÕES DO DIREITO CIVIL: ENSAIO PRELIMINAR
}

\author{
Eroulths Cortiano Junior*
}

RESUMO: Ensaio no qual se expõem idéias introdutórias de uma investigação que tem como objetivo compreender o conceito e o conteúdo do direito civil na atualidade. Parte da noção de que o direito civil sofreu quatro fundações, tendo em cada uma delas objeto e conteúdo distintos. A quarta fundação, ainda em sua dinâmica inicial, representa a superação do direito civil moderno.

\section{DIREITO CIVIL: EM BUSCA DE UM CONCEITO.}

Tema com necessidade de enfrentamento urgente é o do conceito do direito civil. Muitas questões metodológicas e didáticas podem ser bem melhor encaminhadas a partir dessa definição, valendo lembrar que a não-conceituação e também uma forma de conceituar. De qualquer sorte, nesses tempos de reconstrução do direito civil a partir das profundas modificações pelas quais passa sociedade ocidental, notadamente em relação aos valores para cuja proteção a ordem jurídica é chamada, vale refletir sobre o conteúdo do direito civil.

Procuro, neste breve ensaio, trazer algumas breves reflexões que estão servindo

\footnotetext{
${ }^{*}$ Doutor em Direito das Relações Sociais. Professor da Faculdade de Direito da UFPR.
}

a uma reflexão mais profunda, mal iniciada, e que têm como ponto de partida a idéia de é possível falar em quatro fundações distintas do direito civil que, em cada uma delas, teve uma atribuição distinta de conteúdos.

A primeira fundação coincide com Roma e seu jus civile; a segunda com o direito comum do medievo. A elas farei simples e sucinta referência. A terceira fundação ocorre quando da implementação da sociedade burguesa, na modernidade ocidental. Por fim, a quarta fundação é uma fundação ainda in itinere, à qual todos somos chamados a colaborar e fazer, sob pena de não se realizar. Nestas breves reflexões tentarei levantar o véu que encobre a transição entre a terceira e a quarta fundação do direito civil, de forma talvez superficial e singela, mas que servirá, quando menos, para registrar que se está construindo um novo direito civil, fundando uma nova realidade jurídica. 


\section{AS PRIMEIRAS FUNDAÇÕES}

O jus civile nada mais é - ainda que isso não seja pouco - um amplo sistema normativo territorial. Ainda que muitos dos institutos do direito civil moderno e contemporâneo encontrem sua origem e formatação no jus civile, não é possível confundir o conteúdo de um e de outro. O jus civile continha normas que hoje residem em outros setores do direito, como o direito penal e o direito administrativo. De qualquer maneira, no jus civile residiam normas cuja preocupação era a proteção ao cidadão, em um momento histórico que esta expressão não tinha o significado que se lhe dá hoje, mas referenciava o indivíduo submetido à regulação jurídica estatal.

A segunda fundação relaciona-se com a utilização do jus civile e do direito romano como direito comum. O reconhecimento progressivo e a recepção da Recopilação de Justiniano permitem fundar uma ordem em que puderam integrar-se o mercado e o poder político, sem subverter as instituições senhoriais anteriores e sem revolucionar a ordem social precedente, como já assinalava Bartolomé CLAVERO. A colaboração do Corpus Juris Civilis e dos estudos romanistas para a formação dos juristas medievais é fundamental para o surgimento do direito comum europeu, unificador e realizador de um novo discurso jurídico, premissa para o surgimento do direito moderno.

A terceira fundação do direito civil ocorre na modernidade: ele é o pressuposto teórico da experiência européia da constituição da sociedade civil. Ordem teórica necessária e suficiente para a justificação da implementação da sociedade moderna, o direito civil exerce sua função de endossador e sinal de ordem burguesa. Esta terceira fundação é de especial importância para este ensaio.

\section{O DIREITO CIVIL MODERNO}

A burguesia desenvolve uma longa caminhada em busca da transformação da sociedade em acordo com seus interesses. Dominação econômica (possibilitada por sua especial racionalidade econômica e pela crença na mensuração da realidade), dominação intelectual (o burguês é um homem sentado), dominação política (cuja marca visível são as revoluções burguesas, notadamente a de França). Este o percurso bem delineado por Régine PERNOUD em sua obra sobre a burguesia - pelo qual o burguês de então - o homem comum de hoje - constrói a sociedade marcada pelo mercado.

A sociedade de trocas, em que estas são a personagem principal do enredo econômico, somente é possível se estiverem asseguradas a apropriação de bens e a proeminência dos pactos. A sociedade feudal, em que os vínculos pessoais são praticamente orgânicos e o direito de nascença instaura diversos estatutos pessoais, não dá chance à sociedade da mercancia. A livre iniciativa é pressuposto básico da sociedade de mercado, e somente pode ser adequadamente exercida em um ambiente de segurança. A busca dessa segurança gera a modificação das estruturas jurídicas (não só jurídicas: toda a ciência passa a ter outro padrão - o do racionalismo e a mensuração da realidade passa a ser companheira constante do homem em sua vida terrena).

Em primeiro lugar, implanta-se uma ordem jurídica baseada na igualdade e liberdade - 
formais, é bem evidente. A impessoalização do sujeito, para fins jurídicos, é instrumento necessário e suficiente: todos são iguais, porque são livres. E todos são livres porque são iguais.

Em segundo lugar, impõe-se uma clara e bem delineada separação entre Estado e sociedade civil (sendo esta o reino da liberdade, o espaço onde se realizam as trocas), tarefa com a qual colaboram os mais clássicos teóricos da modernidade. Este estancamento (Estado/sociedade civil) gera outros estancamentos ou binômios. A separação entre a esfera pública e a dimensão privada do viver. A distinção entre direito público e direito privado. A imposição de limites ao Estado (com destaque para uma espécie de limitação interna corporis: a doutrina da tripartição dos poderes e o sistema de freios e contrapesos nada mais são do que mecanismos pelo qual o poder do Estado é autolimitado, garantindo segurança para a sociedade civil). A diferenciação entre as funções do juiz e do legislador, este representando o Estado como única fonte produtora do direito. A técnica - na elaboração e na interpretação das normas de subsunção, que limita poderes do juiz. A distinção teórica e prática entre regras (elaboradas com o signo da subsunção) e princípios, com atribuição de força normativa apenas àquelas.

Tudo isto e muito mais marcam a construção jurídica da modernidade. Numa só frase: um direito claro para uma era das certezas. Um direito claro para um mundo de segurança. Um mundo de segurança que logo viria a ruir.

\section{UMA NOVA FUNDAÇÃO PARA O DIREITO CIVIL}

Ainda que as modificações estivessem sendo gestadas desde há muito, é o século XX que vai marcar a superação do mundo da segurança. Século de diversos acontecimentos de forte repercussão nas estruturas sociais. As duas guerras mundiais, fazendo chegar, pela primeira vez, diretamente à população civil seus horrores, seja pela destruição e morte, seja pelo alto índice de convocação de homens para o front, abrindo caminho para a inserção da mulher no mercado de trabalho. A revolução bolchevique e o receio dos países ocidentais de um alastramento das idéias revolucionárias, gerando uma nova estruturação às forças produtivas e o reconhecimento de novos direitos. O reconhecimento, pela ordem jurídica, da figura feminina. O surgimento de novos atores políticos, apresentando reivindicações que passam a ser atendidas pelo Estado, com a conseqüente diluição das fronteiras que o separavam da sociedade civil. Os avanços tecnológicos, abrindo novas possibilidades para a compreensão da existência humana e novas reflexões sobre esta mesma existência. As virtualidades, criando uma nova dimensão de tempo e espaço. A massificação da sociedade, agora uma sociedade de consumo. O fim das fronteiras nacionais. A hipótese da guerra nuclear e o perigo de extinção da humanidade. Uma nova consciência ambiental. Marcas de um novo tempo.

O direito civil clássico, formatado segundo as necessidades de uma outra sociedade e de um outro mundo, não dá conta dessa nova realidade, desses novos tempos. 
Funda-se um novo direito civil. Agora existencialista. A sociedade de massas e de consumo é marcada pela impessoalidade concreta e pela relevação dos valores humanos; tal sociedade escondia a pessoa. A recuperação desta noção de pessoa passa a ser essencial: um sujeito inserido historicamente, com suas fomes, paixões e desejos. Com relações, projetos e planos. Carente de trocas afetivas e de refúgios que lhe devolvam a autonomia, a personalidade e a humanidade.

Algumas marcas jurídicas surgem. A existência de um espaço privilegiado para a proteção da pessoa, situado no encontro entre o direito civil e a Constituição. Uma técnica adequada por intermédio de novas formas de legislar e julgar, notadamente na superação da técnica da subsunção, na legislação por meio de cláusulas gerais e no reconhecimento da força normativa dos princípios. O reconhecimento de uma nova dimensão: a dimensão privada do homem não é formada apenas pelas titularidades, pelos contratos e pelos projetos parentais; entre outros, os temas da igualdade concreta entre as pessoas, da proteção ambiental, da colocação de limites aos avanços tecnológicos de risco, das garantias da cidadania e do valor social do trabalho passam a fazer parte do cotidiano e da vida privada de cada um de nós.

Mas, acima de tudo, está a necessidade da criação de um direito não mais excludente, porém includente. Um direito civil a serviço da vida, na feliz expressão de Orlando de CARVALHO. Neste passo, toma vulto a idéia de uma condição mínima existencial como problema do direito, e do direito civil. Este mínimo existencial envolve problemas de acesso: o acesso às riquezas, com a garantia de um patrimônio mínimo, o acesso à saúde básica, o acesso à educação fundamental e o acesso à justiça.

A quarta fundação do direito civil está em construção: é a fundação de um direito civil de acesso. Um direito civil de dignidade. 